УДК 168.5:5 (075.8) С 25

Свящук А. Л.

doi: 10.32620/gch.2019.1.08

\title{
СОФІЯ ДЛЯ АВІА
}

Статтю присвячено аналізу феноменів нелінійності в літакобудуванні й застосуванню понять і підходів синергетики й теорії систем в авіації.

Ключові слова: нелінійність, точка біфуркації, емерджентність, літальний апарат як складна система.

The article deals with the analysis of phenomena of nonlinearity in aircraft building and application of concepts and approaches of synergetics and the system theory in aviation.

Keywords: nonlinearity, point of bifurcation, emergence, aircraft as a complex system.

Статья посвящена анализу феноменов нелинейности в самолетостроении, а также вопросам применения понятий и подходов синергетики и теории систем в сфере авиации.

Ключевые слова: нелинейность, точка бифуркации, эмерджентность, летательный аппарат как сложная система.

Мета цієї статті - показати, як філософія, а саме її методологічний апарат, може бути використана для пояснення феноменів нелінійності навколишнього світу щодо авіаційної сфери, що має значення в системі підготовки авіаційних інженерів.

Актуальність статті зумовлена слабким застосуванням філософського методологічного апарату в технічних дисциплінах, тоді як автор наполягає на необхідності й корисності застосування гносеологічних і когнітивних ресурсів для розв'язання в тому числі природничо-наукових завдань. У цій статті ми спиратимемося на матеріал i приклади 3 авіації, використовуючи апробовані матеріали лекцій із філософії природознавства, прочитані автором упродовж низки років у XAI для студентів авіабудування, двигунобудування, а також для ITінженерів. Необхідно відзначити, що в історії XAI вже пробували застосувати філософську методологію для пояснення логіки розвитку авіабудування. Так, у навчальному посібнику «Діалектичні основи конструювання» професор Б.Г. Черепенников ілюструє дію діалектичних законів на прикладі розвитку авіаційної техніки і конструкцій [7, с. 27]. Проте, на наш погляд, діалектика не розв'язала покладених на неї завдань; час показав деяку спекулятивність діамату. Наявні й задіяні в той чи той історичний період наукові теорії й підходи, як показав Т. Кун у роботі «Структура наукових революцій» [4], складають те, що він назвав парадигмою. Зараз ми можемо спостерігати неявне або завуальоване зіткнення двох великих принципово різних парадигм - класичної й постнекласичної. Ці парадигми грунтуються на філософських підставах, що суперечать одна одній і не суміщаються, $\mathrm{i}$ припущеннях, у лоні яких сформульовані всі без винятку наукові теорії й підходи, наприклад, теорії й формули аерогідродинаміки, розрахунки на міцність, пояснення 
ефектів турбулентності, надзвукового стрибка й т. ін. Разом із цим уважний розгляд задіяних формул і формулювань дозволяє впевнено сказати, що в низці випадків відбувається занадто явна апроксимація властивостей навколишнього світу, яка доходить іноді до примітивізації й огрублення, що є зовсім недалеким до спотворення реальності. Наприклад, низка формул аеродинаміки має велику емпіричну частину або виведена емпіричним шляхом, що свідчить про недостатність або недосконалість теорії. Або відбувається й зовсім парадоксальна ситуація, коли формулами класичної лінійної парадигми намагаються пояснити нелінійну реальність.

Дійсно, якщо придивитися до формул класичної парадигми, історичне ядро якої складає класична механіка Ньютона, то сам Ісак Ньютон прямо сформулював принципи світоустрою, як він його розумів, у роботі «Математичні начала натуральної філософії» [6, с. 46], де як постулати він висуває наступні: 1. Не треба приписувати природних причин понад ті, які істинні й достатні для пояснення явищ; 2. Слід одним і тим самим наслідкам приписувати за можливістю одні й ті ж причини; 3. Основою наукових доказів є експеримент. Як аксіоми тут покладено наступні онтологічні підстави: простір дискретний; усі процеси протікають в абсолютному просторі й часі. Гносеологічні підстави: лінійний детермінізм; несуперечливий i єдиний опис спостережуваних процесів. Аксіологічні підстави: єдина істина - вища цінність науки; наші знання абсолютно достовірні й об'єктивні для всіх.

Світ Ньютона стаціонарний, стабільний, лінійний. Ціле в механістичній картині - це не більше, ніж сума його складових. Другий закон Ньютона:

$\mathrm{F}=\mathrm{ma}$;

відбиває, наприклад, те, що дія між тілами відбувається миттєво. Результат лінійно пропорційний зусиллю й векторам сил, що впливають. Цей об'єкт прирівнюється до матеріальної точки, а його індивідуальні особливості й геометрія нівелюються. Одна й та сама причина завжди викликає один і той самий наслідок. Події в цьому світі зумовлені. Випадковість і хаос у цій картині світу неможливі й розуміються як міра невивченості. Відзначимо, що класична наука не дає ніякого гносеологічного пояснення тій обставині, що властивості, наприклад, світла, пояснюються одночасно й квантами, і хвилями. Ці й багато інших явищ належать до іншої світоглядної картини.

Невідповідними лінійній картині світу видаються й такі явища аерокосмічної сфери, як турбулентність і раптовий стрибок картини обтікання за переходу на надзвукову швидкість; явища бафтингу й флатеру, настання меж плинності й міцності, раптової втрати стійкості. Ці й інші процеси поводяться нелінійно. Цікавий закон квадрата-куба: із деяким його аналогом зіштовхнулися, коли спробували копіювати під час Другої світової війни американські літаки, розроблені в дюймовій системі в умовах метричної системи радянського машинобудування:

$$
\mathrm{V}_{2}=\mathrm{V}_{1}\left(\mathrm{~L}_{2} / \mathrm{L}_{1}\right)^{3} ; \mathrm{A}_{2}=\mathrm{A}_{1}\left(\mathrm{~L}_{2} / \mathrm{L}_{1}\right)^{2}
$$

коли збільшення якихось лінійних розмірів L літака, наприклад, крила, удвічі призводить до збільшення площі А крила вчетверо, а ваги V - увосьмеро. Із практики машинобудування відомо, що метал тієї ж марки, замовлений на одному підприємстві, може відрізнятися за своїми характеристиками міцності в різні періоди. 
Класична наука не дає відповіді на це практичне питання.

У цивільній авіації в розрахунках на міцність прийнято множити на так званий коефіцієнт безпеки, що дорівнює 1,5 , що $\epsilon$ практичним визнанням неповного розуміння нами процесів реальності. Із розвитком і ускладненням авіаційної й ракетно-космічної техніки літальний апарат (ЛА) став складною системою, до якої застосовують підхід із позиції теорії систем. У авторів книг і підручників з авіаційної тематики розуміння ЛА як складної системи $є$ присутнім, наприклад, деякі викладення ми можемо бачити в С.М. Сгера в «Основах авіаційної техніки» [2, с. 1923], проте викладені положення й правила все ж не вписані в загальну картину нелінійного світу i його нелінійних властивостей. Так, С.М. Сгер пропонує розглядати ЛА як систему, як сукупність взаємопов'язаних керованих компонентів (підсистем), об’єднаних спільною метою функціонування для вирішення заданої проблеми в деякому діапазоні умов. «...Проектуючи ЛА на досить тривалий період експлуатації, ми повинні не лише враховувати сьогоднішній стан зовнішнього середовища, але й уміти прогнозувати його зміни. Прогноз повинен ураховувати зміни зовнішнього середовища, викликані функціонуванням самого ЛА й інших систем, не лише в технічному, але й в екологічному, соціально-політичному й інших аспектах. Оскільки всяка система складається зі взаємопов'язаних компонентів і $є$ певною цілісністю, то зміна параметрів будь-якого з компонентів системи викликає зміну роботи системи i iї вихідних параметрів. Отже, при проектуванні ЛА ми повинні передбачити можливі відмови. Проектування 3 системних позицій - це проектування частини цілого як елементу цілого» [2, с. 22-23].

Якщо відбувається апеляція до теорії систем (не плутати із системним підходом), необхідно відзначити, що дослідженням властивостей систем займається загальна теорія систем у контексті синергетичної парадигми сучасного постнекласичного природознавства, що є обгрунтуванням, універсалізацією й ідеологією нелінійного мислення.

Творці синергетики - Г. Хакен, І. Пригожин, С. Курдюмов - виявили, що у відкритих дисипативних стохастичних системах не діють лінійні залежності як в описі поведінки окремих елементів, так i системи в цілому. Структури еволюціонують не поступово, а стрибкоподібно, проходячи у своїй траєкторії поведінки точки біфуркації, у яких відбувається вибір системою однієї з безлічі альтернатив розвитку; сам вибір відбувається випадковим чином і не пов'язаний 3 лінійною або причинною залежністю з попереднім станом.

Стан порядку змінюється станом невпорядковування й хаосу, перебудовою структур i тяжінням до атракторного стану, що притягує стійкість і порядок. Випадковість і хаос виявляються такими ж нормальними станами системи, як порядок i стійкість. Сама система при цьому розуміється як теоретичний інструмент дослідження об’єкту, конструкт, наше системне його бачення, модель. Цікаво проілюструвати деякі синергетичні принципи й властивості системи на прикладах авіабудування, багато з яких у контексті синергетики з'являється в іншому світлі й розумінні.

Наприклад, до методологічних принципів синергетики належить принцип 
гомеостатичності [1] як підтримка програми функціонування системи в деяких межах із тим, щоб у разі відхилення від заданих параметрів система тяжіла до басейну атракторів - області тяжіння, безлічі розмірності. У авіації в разі повітряних ям, зриву потоку з крила й навіть у разі короткочасної втрати свідомості пілотом і кидання керма передбачена самостабілізація літака в нормальний горизонтальний політ. Для цивільної авіації V поперечне крила зроблено позитивним, щоб вектори підйомних сил створювали стійке положення літака в повітрі, a V поперечне керма висоти завжди трохи більше, ніж крила, щоб у разі заходу за критичні кути атаки зрив потоку на хвостовому оперенні наставав раніше й літак повертався до нормалі. А для літаків, де важливий швидкий відхід 3 лінії атаки, маневреність, наприклад Міг-23, кут V крила поперечне зроблений негативним, щоб відбувалося негайне звалювання вбік у разі потреби.

Найважливіша властивість системи, пов'язана 3 поверненням системи в нормальний стан, - це властивість самоорганізації. У живих системах ця найперша властивість $є$ присутньою як системотвірна, а в штучних системах повинна закладатися як здатність прагнення до стану порядку за виниклих малих відхиленнях - збуреннях. Ієрархічність системи як існування в масштабах різних рівнів, часів, довжин, енергій і т. под. для авіабудування може бути представлена таким чином.

Відомо, що життєвий цикл сучасного цивільного ЛА в середньому може складати близько 30 років експлуатації. Важливо, щоб час життя одних деталей був порівняний із часом життя всієї системи, чого досягають розрахунком деталей конструкції на ресурс, а інші деталі могли б бути замінені або модернізовані на більш ранніх термінах.

Найважливішою в контексті властивості ієрархічності для авіабудування $\epsilon$ властивість підлеглості нижчих порядків і підсистем вищим. Так, проектуючи вузли й агрегати ЛА, інженер зобов'язаний думати не лише про їх функціональні властивості щодо конкретно цього ЛА, а повинен підпорядковувати властивості ЛА вищим системам, таким як системи наземної експлуатації, системи навігації, прийняті у світі (підготовчі й допоміжні засоби [2, с. 25]), екологічні системи, системи життєзабезпечення, транспортні системи й т. д. Це системи, які за масштабами, часом існування коштують дорожче. Таким чином, більше довгожилі й вищі рівні керують нижчими. Міркування екологічності й безпеки вищі, ніж функціональні здатності проектованого ЛА.

На практиці невідповідність порядкам, наприклад, обертається тим, що літак неможливо буде обслужити на аеродромі неосновного базування. Експлуатація виявляє низку таких вимог, які теоретично часом передбачити вкрай складно. Наприклад, «розрахунок на гусака» для кабіни пілота: за потрапляння в кокпіт на швидкості 1000 км/год качка вагою 1 кг перетворюється на снаряд. Окрім цього, сучасні жорсткі економічні умови примушують зазирнути й на 30 років уперед, на останній етап життєвого циклу ЛА - утилізацію. Так, утилізація літака Boeing 747 приносить прибуток близько 15 млн \$: це 6 млн деталей; 66 т першокласного алюмінію; 4 двигуни; велика кількість приладів, які набувають другого життя; 8 км трубопроводів і сотні км кабелів. 
Виходячи з вищесказаного, властивості ієрархічності й підлеглості формулюють свої особливі вимоги до критеріїв вибору ефективності в процесі проектування щодо вищих систем. Украй цікавою для аналізу можливих відмов i аварій ЛА $є$ така властивість системи, як емерджентність, - поява в цілого властивостей, які не були притаманні підсистемам окремо й проявляються тільки в результаті взаємодії. Так, наземне тестування підсистем окремо може дати позитивні результати, а під час запуску все ж статися відмова, що нерідко призводить до аварії. Наприклад, робота ТРД - турбореактивного двигуна - це погоджена спільна взаємодія низки підсистем. Такі прояви з'являються завдяки принципу трьох НЕ - нелінійності, нестійкості, незамкненості. ЛА $€$ відкритою, незамкнутою системою, оскільки постійно обмінюється енергією, інформацією із зовнішнім середовищем. У процесі польоту, коли споживається паливо, вага ЛА змінюється щомиті, змінюється його центрування.

Нелінійна поведінка системи проявляється в стрибкоподібній зміні властивостей на тлі плавної зміни параметрів. Так, із плавним підвищенням температури за 100 градусів за Цельсієм вода перетворюється на пару, а повітряний потік, досягши певних кутів і величин швидкостей, стрибком змінює природу обтікання крила, відбувається стрибок картини обтікання, експонентне збільшення лобового опору або, у разі позамежних кутів атаки, звалювання ЛА в штопор. У області нестійкості на результат і подальший сценарій поведінки може вплинути випадковий чинник. Визнання ролі випадку відрізняє синергетичну картину світу від класичної детерміністської. Синергетика не позбавить від прояву випадкових чинників, але розуміння їх природи дозволяє до них підготуватися. Нелінійний результат - це мало прогнозований, несподіваний сценарій, що відбувається не всупереч природі, а всупереч нашим когнітивним очікуванням.

Багато властивостей матеріалів, конструкцій, систем людина вивчила абсолютно випадково, завдяки «чорним лебедям» і зовсім не завдяки знанням законів фізики, відкритим до того. Так, на зорі авіабудування лист алюмінію для виготовлення обшивки крила розкреслювався за лекалами рисувалкою - гострим металевим стрижнем, що залишає подряпини. А крило працює циклічно, чергуючи напругу розтягування й стискування в шарах металу. Саме після аварій було вивчено явище «втомної тріщини», що розвивається в результаті невеликої подряпини. Коефіцієнт безпеки, запас міцності, прийнятий в авіації, - краща практична ілюстрація того, що ми живемо у світі не закономірностей, а вірогідності. Як говорять квантові інженери, ми можемо бути впевнені в нашому розрахунку мосту на міцність, але ми не можемо бути упевнені в матеріалі мосту, яким чином цього разу сплелися молекули і зв'язки внутрішніх структур.

Синергетична модель світогляду нам потрібна для адекватнішого розуміння нелінійних проявів складних великих систем, для відмови від принципу абсолютної достовірності, а також у ряді випадків від принципу лінійної причинності. Одна й та сама причина може викликати різні наслідки. Лінійне мислення частенько призводить до так званих «когнітивних спотворень», помилок досвіду або помилок неправильних суджень. У першому випадку колишній досвід може закривати вікно можливих нових 
розв’язків, а в другому випадку ми робимо неправильний висновок, грунтуючись не на повній картині ситуації.

В історії авіації відомий випадок, коли під час Другої світової війни математикові й статистикові Абраму Вальду (Abraham Wald) було поставлено завдання: визначити, які частини бомбардувальників треба зміцнити, щоб підвищити шанс їх повернення на базу в тих випадках, коли їм нанесені ушкодження. Деякі судна прилітали, навіть незважаючи на шкоду від супротивника, інші ж не поверталися. Вальд проаналізував ушкодження підбитих літаків, що «дотягли» до бази, і виявив, що частіше за все ушкодження були в хвості, крилах і деяких інших частинах фюзеляжу. Значно менше було машин із підбитими бензобаками й двигунами. На перший погляд логічно зробити висновок, що зміцнювати потрібно саме ті частини, у яких ушкоджень більше. Вальд зробив інший висновок. Раз серед літаків, що повернулися, мало тих, у кого були пошкоджені двигуни й бензобаки, то випливає, що такі літаки на базу просто не повертаються. Відповідно, щоб дати їм шанс, зміцнювати треба саме ці частини. Таким чином, якщо робити висновки тільки виходячи $з$ даних за тими, що вижили (літаками, що повернулися, тобто за частковою вибіркою, що не висвітлює ситуацію цілком), ми прийдемо до неправильних результатів. У свою чергу, аналіз усієї картини кардинально розгортає перебіг думок.

Міркуючи в синергетичному аспекті, для повноти й достовірності висновків про систему - майбутнє ЛА - важливо мати відомості й уявлення про різні рівні системи (конструктор повинен мати уявлення про можливості технолога, проектант - про експлуатанта, усі разом - про пасажира, пілота, техніка літака й навіть про те, які вимоги соціально-економічної й політичної системи можуть бути висунуті через кілька років). Затверджуючи варіант літака, який піде в серійне виробництво, або ж ухвалюючи рішення про перспективну розробку, генеральний конструктор має перед собою десятки варіантів. Потрібний прогностичний аналіз.

Синергетика вчить того, що поведінка складної системи, наприклад ринку, рівнозначна системі, що складається з нескінченного ланцюга зросталих підсистем, їі поведінка слабко прогнозована, i прогнози можливі тільки на певний короткостроковий період. Так, розроблення літака ТУ-144, як і Concorde, виявилося згодом безперспективним, згаяло час і ресурси.

Украй, на наш погляд, цікаві синергетичні міркування, які можна застосувати до генези авіаційної інженерної думки, висловив Сергій Капіца [3]. Система, у цьому випадку світ авіабудування, - це сукупність взаємодій. Міра складності - число зв'язків. Наприклад, якщо в групі 20 студентів і кожен один одному напише повідомлення, то число зв'язків дорівнюватиме 400. Швидкість процесу залежить не стільки від числа учасників, скільки від числа взаємодій між ними. Час прискорюється зі зростанням складності системи. Наш розвиток полягає не лише в знанні, але й у швидкості обміну інформацією.

Завдяки синергетиці відбувається не лише приріст знань, але й розширення пізнавальних здатностей людини за рахунок збагачення нашого мислення синергетичними виразами й конструктами, моделями, які точніше, порівняно 3 класичними детерміністськими, відбивають феномени й прояви навколишнього світу. 
Синергетична картина світу дає розуміння, що відкриті нами закони природи виражають не необхідність і визначеність, а тільки вірогідність і можливість. На відміну від матеріальної точки, уявлення про систему i iii властивості надають можливість зрозуміти «ефект метелика», коли система має місця, де слабка дія здатна викликати ланцюг нелінійних, що впливають один на одного, наслідків, і призвести до кардинального перелаштування архітектоніки структур. Принцип фрактальності надає можливість зрозуміти, що головне в становленні не елементи, а цілісні структури.

Таким чином, викладене дозволяє говорити про іншу, відмінну від класичної, картину світу. Її характеристиками $є$ зростала складність і нелінійність, недовизначеність і взаємозв'язність, глобальність і безповоротність процесів, що відбуваються. Онтологічними принципами світу нових контурів видаються багатоваріантний еволюціонізм i структурність. У питаннях простору й часу однозначних розв'язків бути не може. Дискретна модель, що діє на сьогодні, узята за наукову основу, конвенціональна й прийнята ще за часів Піфагора, але критикована вже тоді Парменідом. Можливість зміни наших уявлень про дискретність простору й абсолютність часу - це не лише положення теорії відносності Ейнштейна, але й перспектива створення техніки на абсолютно інших принципах.

Гносеологічними підставами є передусім методологічний плюралізм і нелінійний детермінізм. Працює принцип фалібілізму: будь-яка теорія має свої межі застосовності й не є ні самою дійсністю, ні істиною в останній інстанції й може бути замінена іншою, досконалішою моделлю. Наприклад, математична модель процесу це всього лише ймовірнісна модель, а не сама реальність. Більш за те, знання часто має не кумулятивний характер, а стрибкоподібний, парадигмальний, і грунтувати додані знання на колишньому досвіді може бути помилкою когнітивних спотворень. Так, поява технології 3-D друку докорінно змінює архітектуру конструкції крила через технологічні можливості, а отже, i методи розрахунку будуть абсолютно іншими й слабко співвідноситимуться $з$ попередніми традиціями.

\section{Лiтература:}

1. Буданов В.Г. Синергетика: история, принципы, современность. URL : http://spkurdyumov.ru/what/sinergetika-istoriya-principy-sovremennost/ (дата звернення 15.02.2019). $576 \mathrm{c}$.

2. Егер С. М., Матвеенко А. М., Шаталов И. А. Основы авиационной техники : учебн. М., 1999.

3. Капииа C. История десяти миллиардов. URL : https://snob.ru/magazine/entry/49621(дата звернення 15.02.2019).

4. Кун T. Структура научных революций. М., 2009. 310 с.

5. Пригожин И. Природа, наука и новая рациональность. М., 1991. №7.

6. Философия современного естествознания : учебн. пособ. для вузов / под общ. ред. проф. С. А. Лебедева. М., 2004. 304 с.

7. Черепенников Б. Г. Диалектические основы конструирования в самолетостроении. Харьков, ХАИ, $1980.128 \mathrm{c.}$ 
References:

1. Budanov V.G. Sinergetika: istoriya, printsipy, sovremennost [Sinergetics: history, principals, modernity] // http://spkurdyumov.ru/what/sinergetika-istoriya-principy-sovremennost/

2. Yeger S. M., Matveyenko A. M., Shatalov I. A. Osnovy aviatsionnoy tekhniki. [fundamentals of aviation technology]Uchebnik. Moskva, 1999. 576 s.

3. Kapitsa S.Istoriya desyati milliardov [ History of ten billions] // https://snob.ru/magazine/entry/49621

4. Kun T. Struktura nauchnykh revolyutsiy. [structure of science revolutions]Moskva, 2009. $310 \mathrm{~s}$.

5. Prigozhin I. Priroda, nauka i novaya ratsional'nost. [Nature, science and moderhity] Moskva, 1991, №7.

6. Filosofiya sovremennogo yestestvoznaniya: Uchebnoye posobiye dlya vuzov. [Philosophy of modern sciense] / Podobshch.red. prof. S. A. Lebedeva. Moskva, 2004. 304 s.

7. Cherepennikov B.G. Dialekticheskiye osnovy konstruirovaniya v samoletostroyenii. [ Dialectical foundations of aircraft construction ]Khar'kov, KHAI, 1980. $128 \mathrm{~s}$.

\section{Andriy Svyashchuk}

\section{SOFIA FOR AVIA}

In the time when the basic formulas and approaches of the aircraft industry are based on the principles of classical science, the nature of the observed phenomena seems nonlinear. Such phenomena as turbulence, flutter, buffering, disruption of the air flow can be explained by means of synergetics and system theory in the context of the post-non-classical paradigm. However, a certain contradiction can be observed: non-linear phenomena are explained by linear traditional science. That is why many formulas of aerodynamics and strength have a large empirical part. Therefore, it becomes necessary to revise the philosophical foundations of most approaches and the overall picture of the world as a whole. The use of the concepts of synergetics and system theory allows us to describe more accurately certain phenomena in aviation, which ultimately will lead to the creation of more efficient and safer aircraft. For example, we can design our aircraft not only as a complex system, but also as part of other complex systems, evaluating its effectiveness from the point of view of more ambitious and higher levels, predicting its operation and modernization in the changing conditions of the socio-political system. Moreover, the very nature of engineering creativity based on synergistic approaches will become more efficient and effective by increasing the intensity of aviation thought. Therefore, understanding the role of chance, the effect of emergence will allow us to be prepared for many surprises and black swans and also be wary about our knowledge, assessing their probabilistic nature.

Keywords: nonlinearity, point of bifurcation, emergence, the plane as a complex system. 


\section{Андрій Свящук}

\section{СОФІЯ ДЛЯ АВІА}

У той час коли формули й підходи традиційної авіаційної галузі грунтуються на класичних формулах і підходах, природа все більше здається нелінійною. Такі явища, як турбулентність, флатер, бафтинг, зрив потоку, можуть бути пояснені за допомогою інструментів синергетики й теорії систем у контексті постнекласичної парадигми науки. Насправді $є$ суперечність: нелінійні явища ми пробуємо пояснити лінійною наукою. Ось чому багато формул мають доволі значну емпіричну частину. Нам необхідно переглянути філософські засади більшості підходів і картину світу в цілому. Використання синергетичних прийомів дасть змогу описати більш тонко деякі явища в авіації, що призведе до появи більш ефективної техніки. Створюючи літак, ми можемо розглядати його як складну систему й частину інших вищих систем, що дозволить більш вдало експлуатувати й бути готовими до модернізації в мінливому світі. Також синергетика робить більш ефективною саму інженерну творчість за рахунок розуміння властивостей емерджентності й ролі випадку, що готує наше мислення до багатьох «чорних лебедів» і несподіванок, i змушує бути обережними із знанням, що часто має вірогідний характер.

Ключові слова: нелінійність, точка біфуркації, емерджентність, літальний апарат як складна система.

Svyashchuk Andriy - Candidate of Philosophy, Associate Professor of the Department of Philosophy Faculty of Humanities of the National Aerospace University «Kharkiv Aviation Institute».

Свящук Андрій - кандидат філософських наук, доцент кафедри філософії Національного аерокосмічного університету ім. М.С. Жуковського «Харківський авіаційний інститут».

e-mail: An20051975@gmail.com

...Для мене знайомство з філософією почалося на лекціях професора Байрачного Кіма Олексійовича, які я слухав студентом ХАI факультету літакобудування. Семінарські заняття вів Каміль Магомедович Магомедов, який був сам закоханим у філософію, зміг настільки залучити, зацікавити, показати красу своєї науки, щзо я, ідейний технар, почав иікавитися працями Декарта та Монтеня, Ніцчие та Локка. Я попросив дозволу відвідувати лекиії аспірантів, і мені, студенту другого курсу, не відмовили. Співробітник кафедри, Більчук Алла Андріївна, з властивою їи глибиною і тонкістю, не будучи офіційно викладачем філософії, але по духу звичайно ж-філософ, завжди зустрічала студентів в методичному кабінеті жартом і розумінням, та могла порадити книгу або джерело по темі, якою ти цікавився, і взагалі, робила спілкування з кафедрою комфортним. Сюди хотілось приходити знову $i$ знову, з иими людьми рости, розвиватися, набиратися знань. Секрет бажання змінити профіль з авіабудівника на філософа, захистити дисертацію $і$ працювати на кафедрі - в людях з якими комфортно: в атмосфері, яка була створена на кафедрі усіма без 
винятку співробітниками, $i$ якій заздрять інші підрозділи $i$ кафедри, у тому, як ми переборюємо негаразди і неприємності, складні часи, не втрачаючи обличчя $і$ особистої гідності. Зараз, відповідаючи на виклики часу, не дивлячись на якусь освітню та академічну розгубленість, бажано зберегти традииї кафедри та поєднати філософський вектор 3 авіачійним профілем XАI, демонструючи наступним поколінням студентів в філософії те, щзо необхідно авіаційному фахівцุю та інженеру.

Свящук Андрій Леонідович - випускник літакобудівного факультету XAI, кандидат філософських наук, доцент кафедри філософії. Навчався в аспірантурі кафедри, під науковим керівництвом проф. Кузнецова А. Ю. підготував і захистив кандидатську дисертацію. Працює на кафедрі 17 років.

Надійшла до редакції 01.03.2019. Розглянута на редколегії 18.03.2019.

\section{Рецензенти:}

Доктор філософських наук, професор, професор кафедри суспільно-гуманітарних дисциплін Харківського Національного університету будівництва та архітектури Проценко О.П.

Доктор філософських наук, професор, головний науковий співробітник відділу гуманітарної політики Національного інституту стратегічних досліджень при Президентові України Степіко М.Т. 